\title{
Transoceanic Disperse of the White-lipped Island Pit Viper (Cryptelytrops insularis; Kramer,1997) from Sundaland to Lesser Sunda, Indonesia
}

\author{
Bagus Priambodo ${ }^{1,2,3}$, Fu-Guo Robert Liu², Nia Kurniawan ${ }^{1}$ \\ ${ }^{1}$ Department of Biology, Faculty of Mathematics and Natural Sciences, University of Brawijaya, Malang \\ ${ }^{2}$ Department of Life Sciences, National Central University, Taiwan \\ ${ }^{3}$ Department of Biology, Faculty of Mathematics and Natural Sciences, State University of Malang
}

\begin{abstract}
White-lipped island pit viper (Cryptelytrops insularis) is one of the most distributed Viperidae in Indonesia, especially in eastern part of Sundaland and Lesser Sunda. To investigate the evolutionary history and the dispersal pattern of $C$. insularis, we collected 23 samples from 11 localities. Four simultaneous genes composing two mitochondrial genes (16S rRNA \& ND4) and two nuclear genes (7IBFIB \& 3ITBP) have been successfully amplified and sequenced. Bayesian inference was performed to reconstruct the phylogeny tree. Furthermore, time divergence and the population demography analyses were estimated. The phylogeny tree of $C$. insularis exhibits monophyletic group, with four geographically structured lineages. The time divergence estimation indicated that $C$. insularis evolved at approximately 7 million years ago (mya). Population demography was inferred by Bayesian Skyline Plot analysis, it shows that the population increased constantly from the past to recent time. The evolutionary history of $C$. insularis can be explained by a pattern of the time divergences estimation that indicating movement from West (Java) to East (Lesser Sunda). We expected that the dispersal factor of $C$. insularis into many different islands (in Lesser Sunda) is caused by the animal helped and also oceanic rafting which could be the stepping stones to another island.
\end{abstract}

Keywords: Cryptelytrops insularis, dispersal patterns, phylogeny, population demography, time divergence

\section{INTRODUCTION}

Indonesia was one of some biggest hotspot biodiversity in the world, especially the Sundaland and Wallacea area [1]. There are 5 large islands, Sumatra, Java, Kalimantan, Sulawesi, Papua New Guinea, and around 17.000 small islands. [2]. These islands have unique geographical history leading to unique biological evolution.

During Pliocene approximately 5 million years ago (mya) and Pleistocene (12000 years ago) Epoch, there were several sea level fluctuations due to the glaciations [3]. At that time, the Sundaland area including Sumatra, Java, and Borneo was in a changing phase, and also the unity of Sulawesi and the appearance of Lesser Sunda were formed due to the collisions of Philipines and Australian plates [4]. These periods were suggested to affect recent animal compositions [3]. The lowering of sea level caused the emergence of some landbridges for dispersal. In contrast, the raising of sea level will inundate some islands and coastal plain, and restrict the dispersals of some fauna [5]. During the period of isolation, organisms would evolve independently such as snake [6].

\footnotetext{
*Correspondence address:

Bagus Priambodo

Email : priambodo.fmipa@um.ac.id

Address : Dept. Biology, State University of Malang, Jl.

Semarang 5 Malang 65145
}

Insular species was very interesting to study the evolution and biogeography because they are separated by islands [7]. Cryptelytrops insularis (Trimeresurus insularis) or white-lipped island pit viper was one of the insular species that distributed in Java, Bali, Adonara, Alor, Flores, Komodo, Lombok, Padar, Rinca, Romang, Roti, Sumba, Sumbawa, Timor, and Wetar [8,9]. Based on the Reptile Database this species has type locality from Timor Island [8]. This species was well-distributed in Java, Bali (Sundaland) and Lesser Sunda, but in fact between Sundaland and Leser Sunda are never been connected. Thus, we raised a question, how can $C$. insularis dispersed into those islands?

Robust phylogeny on the genus level of Trimeresurus (previous scientific genus name) were done by Maholtra \& Thorpe [10], Creer et al [11], Maholtra \& Thorpe [12], Creer et al [13], and Maholtra et al [14], but intra-species level on each species still unclear. Based on molecular assessment using Cyt B David et al [15] showed that $C$. insularis has a close relationship with Cryptelytrops fasciatus from Tanahjampea Island, South Sulawesi. Interestingly, there is another viper whose distribution overlapped with $C$. insularis, namely Cryptelytrops albolabris. But, the relationship is closer to $C$. fasciatus than $C$. albolabris which have similar morphology [14]. We hypothesize that geographical history might influence their relationships as well. Therefore, 
using more genes and more samples we have aimed to evaluate the phylogeny and biogeography of white-lipped island pit viper, and also to estimate their dispersal patterns.

\section{MATERIALS AND METHODS \\ Sample collection}

We collected a total of 23 samples including one outgroup (Cryptelytrops albolabris) and two samples from Genbank (NCBI) [16]. Sample collections were conducted during May 2016 January 2017, in Java, Bali, and Lombok Islands. Visual Encounter Survey (VES) method was used to collect the sample by looking around the tracking area [17]. Additional sequences were obtained from Genbank NCBI (Supplementary 1). Tissues collection was taken from muscle, tail tips, and liver then preserved into $1.5 \mathrm{~mL}$ tubes containing $98 \%$ ethanol or lysis buffer (Tris, EDTA, and SDS). Specimen's whole body were preserved into $70 \%$ ethanol and stored in the room temperature.

\section{Molecular protocols}

DNA extraction was conducted by QIAGEN kit (QIAamp DNA Minikit, Hilden, Germany) and following their protocol, also by manual procedure with phenol and chloroform. Tissue digestion conducted with $330 \mu \mathrm{L}$ STE buffer (cell lysis buffer) (10 mM Tris- $\mathrm{HCl}$ pH 5.0, $0.1 \mathrm{NaCl}, 1$ mM EDTA), $40 \mu \mathrm{L} 20 \%$ SDS, and $20 \mu \mathrm{L}$ of 20 $\mathrm{mg} \cdot \mathrm{mL}^{-1}$ Proteinase $\mathrm{K}$ [18]. DNA pellet was

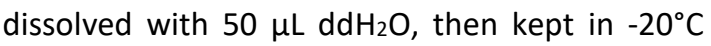
freezer for later use.

We used two mitochondrial genes (16S rRNA and ND4) and two nuclear genes (7IBFIB and 3ITBP). These genes were succeeded to amplify Asian pit viper and generated well-resolved phylogeny [13]. Primers used were shown in Supplementary 2. PCR mixture composition was followed by the 2x Taq DNA Polymerase Master mix RED reaction composition (BIONOVAS, Toronto, Ontario). Thermal cycles used were: pre-denaturation at $94^{\circ} \mathrm{C}$ for 1 -minute, then followed by 40 cycles of 30 seconds denaturation at $94^{\circ} \mathrm{C}, 1-3$ minutes annealing at $50-57^{\circ} \mathrm{C}$ and $1-$ minute extension at $72^{\circ} \mathrm{C}$. then $10-15$ minutes final extension at $72^{\circ} \mathrm{C}$. We have a difficulty in the nuclear genes amplification, the PCR products were amplified with an unstable successful rate. In order to increase the sensitivity, a nested PCR approach was applied [19]. PCR products were cleaned up with PCR Advanced Clean-Up System (VIOGENE). These four genes were completely sequenced from both directions with the following primers in
Biomedical Research Center at Academia Sinica and Mission Biotech (Taiwan), using ABI PRISM Model 3730 Version 3.2.

\section{Sequences analyses}

Sequences were aligned by Clustal $\mathrm{W}$ and modified implemented in MEGA 7 [20], then double-checked manually with FinchTV 1.4.0 [21]. Phylogenetic trees were reconstructed using Bayesian inference (BI), with the best fit model of $\mathrm{GTR}+\mathrm{I}+\mathrm{G}$ (general time-reversible + Proportion invariable sites + gamma distribution) was selected with Akaike information criterion (AIC) by jModeltest 2.1.10 [22,23]. The parameter for Proportion invariable was 0.6583 and for gamma/shape was 0.7690. BI was estimated using MrBayes 3.2.3 with two runs of four Monte Carlo Markov chains for 100.000 .000 generations and a tree was sampled every 100 generations [24]. The consensus topology was summarized with burn-in first $25 \%$ trees.

Time divergence was estimated using BEAST v1.8.4 [25]. The parameters were set up in BEAUti v1.8.4 as GTR substitution model, empirical base frequencies, 6 number of gamma categories, random local clock model, Coalescent; constant size tree prior. At the Prior column, fossil records calibration used are: (i). Cryptelytrops insularis divergence around 8.5 million years ago (mya), (ii). Cryptelytrops albolabris divergence around 7.15 mya [26]. For the alpha parameter used is gamma distribution; Initial value/shape=0.6583), and for the Pinvariable the parameter used is lognormal distribution with Initial value/mean $=0.6583$, stdev $=0.32915$ ) then using 200.000 .000 chain length. The BEAST was performed with two independent runs. The BEAST log result was checked by TRACER 1.6 [27] estimations to check the validity of convergence and effective sample size (ESS). Two BEAST tree files then combined by the LogCombiner v1.8.4, then the combined tress would summarize by TreeAnnonator v.1.8.4. then the time-calibrated tree was visualized and modified by FigTree v.1.4.3.

Bayesian skyline plot (BSP) was performed by BEAST v.1.8.4 [25] to estimates changes in effective population size through the time. The analysis was conducted at all individuals which belong to Cryptelytrops insularis (22 individuals). The parameter for the tree prior was used the Coalescent; Bayesian Skyline, and for the time calibration used was 7.15 mya for $C$. insularis [26]. The BEAST file was double generated in 
3.000.000 chain length. The BSP result was analyzed and visualized by TRACER 1.6 [27].

\section{RESULTS AND DISCUSSION}

Phylogenetic tree and genetic distances

To determine the phylogeny of 22 individuals in Cryptelytrops insularis, Bayesian inference tree was constructed based on 3575 base pairs sequences from 4 simultaneous genes (16S rRNA, ND4, 7IBFIB, and 3ITBP).

Our phylogenetic tree based on 4 simultaneous genes showed a monophyletic group with four clades (Fig. 1). Clade A containing C. insularis samples from Lesser Sunda area such as Lombok and Timor, while Clade E consisting samples from Sundaland such as Java and Bali. In detail, Clade $B$ consisted of $C$. insularis from East Java, Clade $C$ are composed of samples from Bali Island, and Clade E consisted of samples from East Java. Most of the posterior probability on the nodes were weakly supported by Bayesian Inference, however, there were some nodes received high supports such as Clade $C$ and the common ancestor of Clade B, C, and D.

The genetic distances among clades are varied between individuals (Table 1 ), but there are no significant genetic differences. The highest genetic differences were 0.009 and 0.008 which showed on samples from East Java (sample no. 1) with the sample from Bondowoso, East Java (sample no. 22), and samples from Bondowoso, East Java (sample no. 22) with the sample from Tanah Lot, Bali (sample no. 56), respectively.

\section{Divergence times estimation}

Divergence time estimation indicated that $C$. insularis was younger than C. albolabris (Fig. 2). Most ancient $C$. insularis evolved around 7 mya (node $a$ ), then followed by first diversification on the node b, around 6.7 mya in Sundaland area (Java and Bali). Samples from Lesser Sunda (node c) diverge around 4 mya. Based on our estimations we expected that there is an eastward movement of $C$. insularis.

\section{Population demography (Bayesian skyline plot)}

To estimate the effective population size through the time, we performed the Bayesian skyline plot (BSP) on Figure 3. BSP analysis on $C$. insularis population showed increased constantly from the past to recent time. At the first diversification of $C$. insularis around 7-5 mya, the effective population size was increased slightly. Moreover, around 5-3 mya the population size was increased significantly. Then around 3 mya to recent time, the population size estimation showed the most stable with slightly increase.

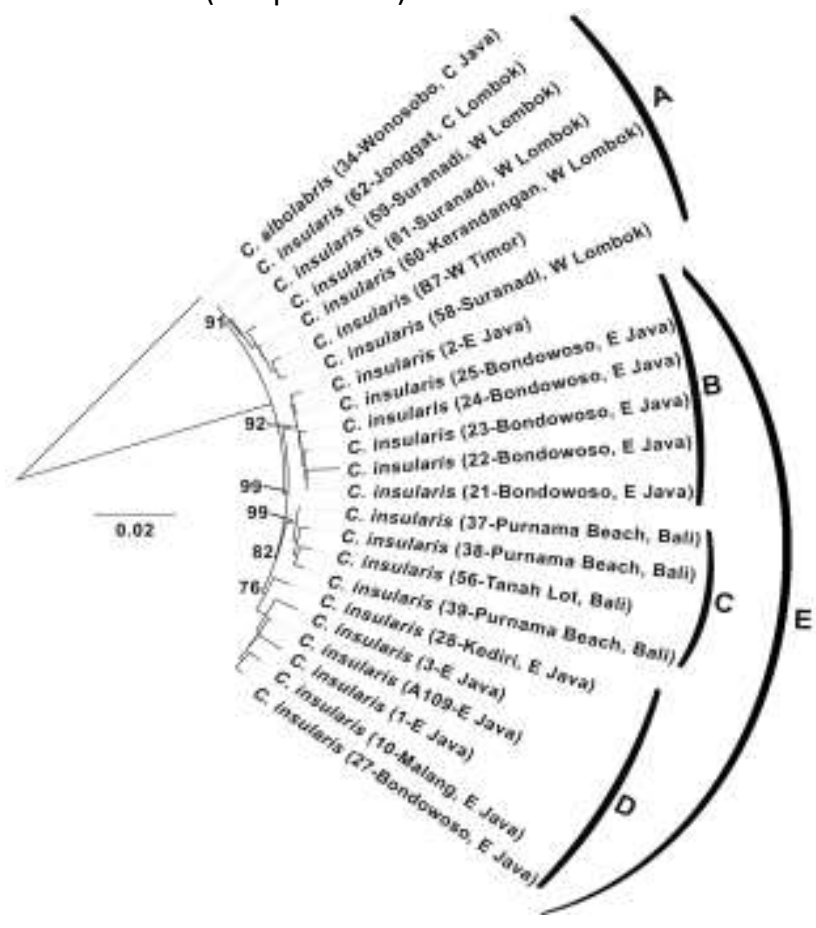

Figure 1. Bayesian phylogeny semi circular-tree based on 4 simultaneous genes (16S rRNA, ND4, 7IBFIB \& 3ITBP). C. albolabris was used as an outgroup. The number on the nodes represent the Bayesian posterior probability (pp). Sample number and locality were showed in parentheses. (C: Central, E: East, W: West). 


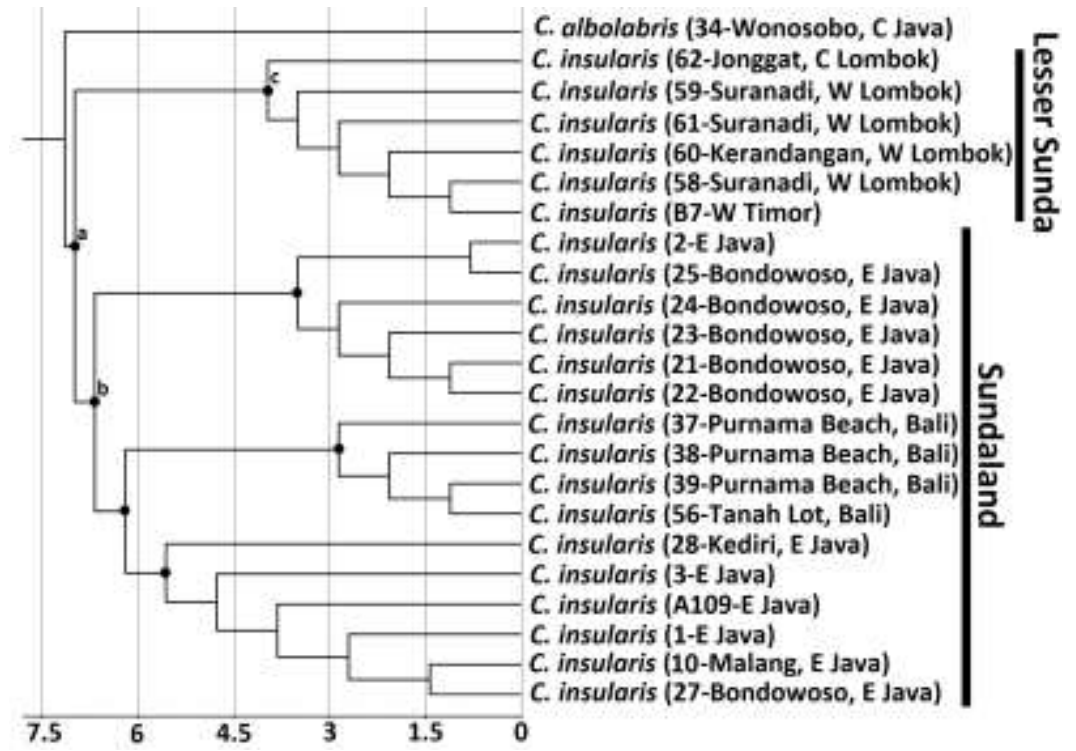

Figure 2. Time-calibrated tree based on 4 simultaneous genes (16S rRNA, ND4, 7IßFIB \& 3ITBP). Sample number and locality were showed in parentheses. The scaled line below the trees represents the time in million years ago. The alphabets on the nodes represent the divergence time which explained in the results section (C: Central, E: East, W: West).

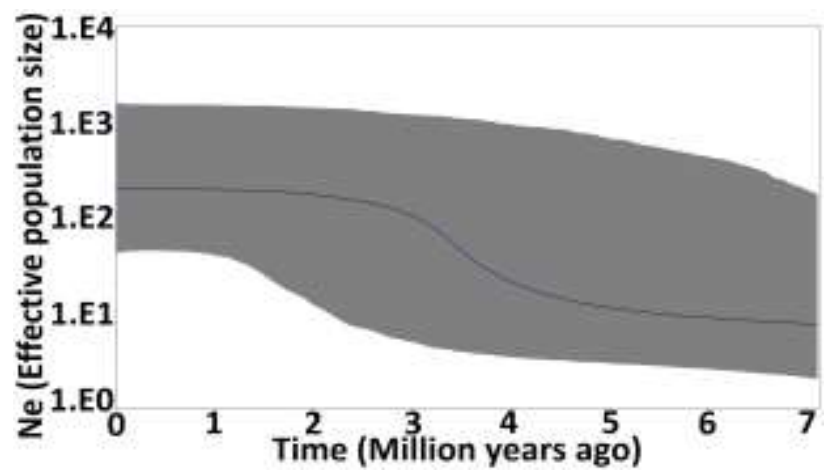

Figure 3. Bayesian Skyline Plot illustrating effective population size (Ne) through the time on Cryptelytrops insularis. Grey solid color represent $95 \%$ posterior probability range. Blackline represents the median population size.

\section{Historical biogeography and population} demography of Cryptelytrops insularis

Java and Bali emerged to the surface by 10 mya and then followed by Lombok and Sumbawa by 5 mya [28]. The emergence of younger islands to the east, starting from Bali to Lombok, Sumbawa, Flores, and Wetar were corresponding to the relationship in our phylogeny tree [29]. Seems, our time divergences analysis also demonstrate the same condition, which samples from Java-Bali was oldest then followed by Lesser Sunda's sample.

Timor was emerged around 2 mya, as the result of the collision between Australian continental margin and the Banda volcanic arc. [3,30-32]. These reports strengthen our findings, that sample from Timor is the youngest one than another which is included in Lesser Sunda.

During Miocene Epoch, warm temperature, humid climate, and rainforest habitat were predominated thus provided organisms suitable habitats [34]. However, started from Pliocene (around 3 mya) to recent the temperature was cold, even extremely cold $[35,36]$. In such conditions, some organisms might experience population fluctuation and even extinction [37]. But, C. insularis population are constantly increased. We suggested that this species has a strong survival rate to adapt in several conditions and habitat, especially cold temperature [35].

\section{Dispersion probability}

Java and Bali's islands have experience of being connected by the shallow sea during Pleistocene [3]. Java and Bali shared a lot of welldistributed fauna such as avians and mammals [38]. Other evidence showed in freshwater fishes, a total of 227 species spread in Java and Bali [39]. 


\section{(Priambodo et al)}

Table 1. Genetic distances with the selected parameters based on jModeltest. Evolutionary model= GTR+l+G, Proportion of invariable sites $(I)=0,6583$ and Gamma distribution shape parameter $=0,7690$. The number in bold showed the most significant genetic differences. Sample number and locality were showed in parentheses. (C: Central, E: East, W: West).

\begin{tabular}{|c|c|c|c|c|c|c|c|c|c|c|c|c|c|}
\hline & & 1 & 2 & 3 & 4 & 5 & 6 & 7 & 8 & 9 & 10 & 11 & 12 \\
\hline 1 & Cryptelytrops insularis (1-E Java) & - & & & & & & & & & & & \\
\hline 2 & C. insularis (2-E Java) & 0.004 & - & & & & & & & & & & \\
\hline 3 & C. insularis (3-E Java) & 0.003 & 0.003 & - & & & & & & & & & \\
\hline 4 & C. insularis (10-Malang, E Java) & 0.003 & 0.004 & 0.002 & - & & & & & & & & \\
\hline 5 & C. insularis (21-Bondowoso, E Java) & 0.004 & 0.001 & 0.003 & 0.003 & - & & & & & & & \\
\hline 6 & C. insularis (22-Bondowoso, E Java) & 0.009 & 0.004 & 0.005 & 0.006 & 0.003 & - & & & & & & \\
\hline 7 & C. insularis (23-Bondowoso, E Java) & 0.005 & 0.001 & 0.003 & 0.004 & 0.000 & 0.004 & - & & & & & \\
\hline 8 & C. insularis (24-Bondowoso, E Java) & 0.005 & 0.001 & 0.003 & 0.003 & 0.000 & 0.004 & 0.000 & - & & & & \\
\hline 9 & C. insularis (25-Bondowoso, E Java) & 0.005 & 0.000 & 0.003 & 0.003 & 0.000 & 0.004 & 0.000 & 0.000 & - & & & \\
\hline 10 & C. insularis (27-Bondowoso, E Java) & 0.003 & 0.002 & 0.002 & 0.002 & 0.001 & 0.004 & 0.001 & 0.001 & 0.001 & - & & \\
\hline 11 & C. insularis (21-Kediri, E Java) & 0.004 & 0.003 & 0.003 & 0.003 & 0.003 & 0.006 & 0.003 & 0.002 & 0.002 & 0.003 & - & \\
\hline 12 & C. insularis (21-Purnama Beach, Bali) & 0.004 & 0.003 & 0.003 & 0.004 & 0.002 & 0.006 & 0.003 & 0.002 & 0.002 & 0.003 & 0.002 & - \\
\hline 13 & C. insularis (38-Purnama Beach, Bali) & 0.005 & 0.004 & 0.003 & 0.004 & 0.004 & 0.006 & 0.004 & 0.004 & 0.004 & 0.003 & 0.003 & 0.001 \\
\hline 14 & C. insularis (39-Purnama Beach, Bali) & 0.003 & 0.004 & 0.002 & 0.003 & 0.003 & 0.006 & 0.004 & 0.004 & 0.004 & 0.002 & 0.003 & $0, .001$ \\
\hline 15 & C. insularis (56-Tanah Lot, Bali) & 0.004 & 0.004 & 0.003 & 0.004 & 0.004 & 0.008 & 0.005 & 0.005 & 0.004 & 0.004 & 0.005 & 0.002 \\
\hline 16 & C. insularis (58-Suranadi, W Lombok) & 0.005 & 0.003 & 0.003 & 0.005 & 0.002 & 0.006 & 0.003 & 0.003 & 0.002 & 0.004 & 0.003 & 0.003 \\
\hline 17 & C. insularis (59-Suranadi, W Lombok) & 0.004 & 0.002 & 0.002 & 0.004 & 0.001 & 0.006 & 0.002 & 0.002 & 0.001 & 0.003 & 0.003 & 0.003 \\
\hline 18 & C. insularis (60-Kerandangan, W Lombok) & 0.004 & 0.003 & 0.003 & 0.004 & 0.003 & 0.006 & 0.003 & 0.003 & 0.002 & 0.004 & 0.004 & 0.003 \\
\hline 19 & C. insularis (61-Suranadi, W Lombok) & 0.005 & 0.003 & 0.003 & 0.005 & 0.003 & 0.007 & 0.003 & 0.003 & 0.003 & 0.004 & 0.004 & 0.003 \\
\hline 20 & C. insularis (62-Jonggat, C Lombok) & 0.004 & 0.002 & 0.002 & 0.003 & 0.001 & 0.006 & 0.002 & 0.002 & 0.001 & 0.003 & 0.003 & 0.002 \\
\hline 21 & C. insularis (A109-E Java) & 0.005 & 0.002 & 0.000 & 0.001 & 0.002 & 0.002 & 0.003 & 0.002 & 0.002 & 0.002 & 0.001 & 0.002 \\
\hline 22 & C. insularis (B7-W Timor) & 0.006 & 0.003 & 0.003 & 0.004 & 0.003 & 0.002 & 0.003 & 0.003 & 0.002 & 0.004 & 0.005 & 0.003 \\
\hline 23 & Cryptelytrops albolabris (34-Wonosobo, C Java) & 0.052 & 0.052 & 0.053 & 0.067 & 0.057 & 0.072 & 0.063 & 0.064 & 0.062 & 0.067 & 0.066 & 0.067 \\
\hline
\end{tabular}

Table 1. Continue

\begin{tabular}{|c|c|c|c|c|c|c|c|c|c|c|c|c|}
\hline & & 13 & 14 & 15 & 16 & 17 & 18 & 19 & 20 & 21 & 22 & 23 \\
\hline 13 & C. insularis (38-Purnama Beach, Bali) & - & & & & & & & & & & \\
\hline 14 & C. insularis (39-Purnama Beach, Bali) & 0.002 & - & & & & & & & & & \\
\hline 15 & C. insularis (56-Tanah Lot, Bali) & 0.002 & 0.002 & - & & & & & & & & \\
\hline 16 & C. insularis (58-Suranadi, W Lombok) & 0.003 & 0.003 & 0.004 & - & & & & & & & \\
\hline 17 & C. insularis (59-Suranadi, W Lombok) & 0.003 & 0.003 & 0.003 & 0.001 & - & & & & & & \\
\hline 18 & C. insularis (60-Kerandangan, W Lombok) & 0.003 & 0.003 & 0.003 & 0.001 & 0.001 & - & & & & & \\
\hline 19 & C. insularis (61-Suranadi, W Lombok) & 0.003 & 0.004 & 0.004 & 0.002 & 0.002 & 0.001 & - & & & & \\
\hline 20 & C. insularis (62-Jonggat, C Lombok) & 0.003 & 0.003 & 0.003 & 0.001 & 0.000 & 0.001 & 0.002 & - & & & \\
\hline 21 & C. insularis (A109-E Java) & 0.003 & 0.002 & 0.003 & 0.003 & 0.002 & 0.001 & 0.003 & 0.001 & - & & \\
\hline 22 & C. insularis (B7-W Timor) & 0.003 & 0.003 & 0.002 & 0.001 & 0.001 & 0.001 & 0.001 & 0.001 & 0.002 & - & \\
\hline 23 & Cryptelytrops albolabris (34-Wonosobo, C Java) & 0.067 & 0.053 & 0.053 & 0.051 & 0.052 & 0.050 & 0.051 & 0.058 & 0.060 & 0.042 & - \\
\hline
\end{tabular}

J.Exp. Life Sci. Vol. 9 No. 1, 2019 
The existence of landbridge between Java and Bali might play an important role in $C$. insularis dispersal [3].

Between Bali and Lombok, there is a deep strait which is known as fauna discontinuation, called by Wallace's line [38]. But this Wallace line has no effect on $C$. insularis, this species is well distributed eastward to Timor, despite being separated by inter-island barriers [40]. Therefore, we suggested that there is an intervention of another animal, which influenced the movement of $C$. insularis from Bali to Lombok.

Komaki et al suggested that there are two possibilities for terrestrial animal transoceanic dispersal, ocean flow or carry by other animals with high dispersal ability (birds or human) [41]. However, at that time (around 4 mya) humans did not exist yet [42]. Therefore, we convinced that the dispersal pattern from Bali to Lombok was helped by birds. $C$. insularis categorized in the Viperidae Family which usually less-mobile compared to other families [9]. This behavior could also enhance the chance for birds to catch this species then moved to another place.

Zoologists explained that insects, mammals, and reptiles have been demonstrated the transoceanic dispersal by rafting [43-45]. Some floating stuff such as macroalgae, pumice, wood, and vegetation could be a substrate for the snake to hold up $[41,46]$. The ocean drift usually following the ocean throughflow and winds [46].

The eastward distribution of $C$. insularis from Lombok until Timor is more likely to be helped by ocean flow from the Pacific Ocean [28]. Water flows from the north (Makassar Strait) head eastward from Lombok to Timor. Then the throughflow circled Timor (to the south of Timor) and turned west toward the Indian Ocean $[28,47,48]$. Another viper species which exhibit a similar distribution is Cryptelytrops albolabris [8]. However, there is no report or genetic data of $C$. albolabris from Lesser Sunda.

\section{CONCLUSION}

Our phylogeny showed monophyletic group, Sundaland and Lesser Sunda were geographically separated with independent common ancestor. Cryptelytrops insularis started to evolve around 7 million years ago, then followed by first diversification around 6.7 mya in Sundaland area (Java and Bali). Samples from Lesser Sunda diverge around 4 mya. The $C$. insularis transoceanic dispersal are observed with eastward movement. We tend to believe that, the overseas dispersal is helped by other animal and rafting by the ocean drift. We still don't have complete samples representing all the islands in the Lesser Sunda. Therefore, more samples from other localities were needed for further research to explore the biogeography of $C$. insularis.

\section{ACKNOWLEDGMENT}

We are very grateful to NK Research members: A.M. Kadafi, Agung Sih K., M. Alif, Ari A., M. Fathoni, M. Fahmi, Anggun S.F., for the valuable work on sample collection and providing information about Cryptelytrops insularis. This research was funded by PEER-USAID.

\section{REFERENCES}

[1] Sodhi, N.S., L.P. Koh, B.W. Brook, P.K.L. Ng. 2004. Southeast Asia biodiversity: an impending disaster. Review in TRENDS in Ecology and Evolution. 19.

[2] Iskandar, D.T., W.R. Erdelen. 2006. Conservation of amphibians and reptiles in Indonesia: issues and problems. Amph. Reptile Conserv. 4. 60-87.

[3] Lohman, DJ., M. de Bruyn, T. Page, K. von Rintelen, R. Hall, K.L. Ng, Peter, H.T. Shih, G.R. Carvalho, T. von Rintelen. 2011. Biogeography of the Indo-Australian Archipelago. Annu. Rev. Ecol. Evol. Syst. 42. 205-226.

[4] Hall, R. 1998. The plate tectonics of Cenozoic SE Asia and the distribution of land and sea. Biogeography and Geological Evolution of SE Asia. 99-131.

[5] Voris, H.K. 2000. Maps of Pleistocene sea levels in Southeast Asia: shorelines, river systems and time durations. J. Biogeogr. 27. 1152-1167.

[6] Molengraaff, G., M. Weber. 1921. On the relation between the Pleistocene glacial period and the origin of the Sunda Sea (Java and South China-Sea), and its influence on the distribution of coral reefs and on the land and freshwater fauna. Proc. R. Acad. Amsterdam. 23. 395-439.

[7] Boback, S.M. 2003. Body size evolution in snakes: evidence from island populations. Copeia. 1. 81-94.

[8] Uetz, P., T. Etzold. 1996. The EMBL/EBI Reptile Database. Herpetol. Rev. 27. 174175.

[9] Marlon, R. 2014. Panduan visual dan identifikasi lapangan: 107+ ular Indonesia. Indonesia Nature and Wildlife Publising.

[10] Maholtra, A., R.S. Thorpe. 2000. A phylogeny of the Trimeresurus group if pit vipers: new evidence from a mitochondrial 
gene tree. Mol. Phylogenetics Evol. 16. 199211.

[11] Creer, S., A. Maholtra, R.S. Thorpe. 2003. Assessing the phylogenetic utility of four mitochondrial genes and a nuclear intron in the Asian Pit Viper genus, Trimeresurus: separate, simultaneous, and conditional data combination analyses. Mol. Biol. Evol. 20. 1240-1251.

[12] Maholtra, A., R.S. Thorpe. 2004. A phylogeny of four mitochondrial gene regions suggests a revised taxonomy for Asian pitvipers (Trimeresurus and Ovophis). Mol. Phylogenetics Evol. 32. 83-100.

[13] Creer, S., C.E. Pook, A. Maholtra, R.S. Thorpe. 2006. Optimal intron analyses in the Trimeresurus radiation of Asian Pitvipers. Syst. Biol. 55. 57-72.

[14] Maholtra, A., S. Creer, C.E. Pook, R.S. Thorpe. 2010. Inclusion of nuclear intron sequence data helps to identify the Asian sister group of New World pitvipers. Mol. Phylogenetics Evol. 54. 172-178.

[15] David, P., G. Vogel, N. Vidal. 2003. On Trimeresurus fasciatus (Boulenger, 1896) (Serpentes: Crotalidae), with a discussion on its relationships based on morphological and molecular data. Raffles Bull. Zool. 51. 149-157.

[16] Benson, D.A., I. Karsch-Mizrachi, D.J. Lipman, J. Ostell, D.L. Wheeler. 2005. GenBank. Nucleic Acids Res. 33. 34-38.

[17] Menegon, M.2007. Methods for surveying and processing reptiles and amphibians of Alpine springs. In: Cantonati, M., E. Bertuzzi, D. Spitale (Eds). The Spring Habitat: Biota and Sampling Methods. Museo Tridentino di Scienze Naturali, Trento. 275-285.

[18] Kocher, T.D., W.K. Thomas, A. Meyer, S.V. Edwards, S. Paabo, F.X. Villablanca, A.C. Wilson. 1989. Dynamics of mitochondrial DNA Evolution in animals: Amplification and sequencing with conserved primers. Proc. Nati. Acad. Sci. USA. 86. 6196-6200.

[19] Boon, N., W.D. Wind, W. Verstraete, E.M. Top. 2002. Evaluation of nested PCR-DGGE (denaturing gradient gel electrophoresis) with group-spesific 16S rRNA primers for the analysis of bacterial communities from different wastewater treatment plants. FEMS Microbiol. Ecol. 39. 101-112.

[20] Kumar, S., G. Stecher, K. Tamura. 2016. MEGA7: Molecular Evolutionary Genetics Analysis Version 7.0 for Bigger Datasets. Mol. Biol. Evol. 33. 1870-1874.
[21] Patterson, J., B. Chamberlain, D. Thayer 2006. Finch TV Version 1.4.0. Available at: http://www.geospiza.com/Products/finchtv .shtml

[22] Guindon, S., O. Gascuel. 2003. A simple, fast, and accurate algorithm to estimate large phylogenies by maximum likelihood. Syst. Biol. 52. 696-704.

[23] Darriba, D., G.L. Taboada, R. Doallo, D. Posada. 2012. jModelTest 2: more models, new heuristics and parallel computing. Nature Methods. 9. 772.

[24] Huelsenbeck, J.P., F.R. Ronquist. 2001. MrBayes: Bayesian Inference of Phylogenetic Trees. Bioinformatics. 17. 754755.

[25] Drummond, A.J., M.A. Suchard, D. Xie, A. Rambaut. 2012. Bayesian phylogenetics with BEAUti and the BEAST 1.7. Mol. Biol. Evol. 29. 1969-1973.

[26] Zhu, F., Q. Liu, J. Che, L. Zhang, X. Chen, F. Yan, R. Murphy, C. Guo, P. Guo. 2016. Molecular phylogeography of white-lipped tree viper (Trimeresurus; Viperidae). Zoologica Scripta. 45. 252-262.

[27] Rambaut, A., M.A. Suchard, D. Xie, A.J. Drummond. 2014. Tracer v1.6. Institute of Evolutionary Biology, University of Edinburgh.

[28] Hall, R. 2009. Southeast Asia's changing palaeogeography. Blumea. 54. 148-161.

[29] Hall, R., I. Sevastjanova. 2012. Australian crust in Indonesia. Aust. J. Earth Sci. 59. 827-844.

[30] Carter, D.J., M.G. Audley-Charles, A.J. Barber. 1976. Stratigraphical analysis of island arc-continental margin collision in eastern Indonesia. J. Geol. Soc. 132. 179189.

[31] Hamilton, W. 1979. Tectonics of the Indonesian region, Geological Survey Professional Paper 1078. U.S. Government Printing Office, Washington.

[32] Audley-Charles, M.G. 2011. Tectonic postcollision processes in Timor. In: Hall, R., M.A. Cottam, M.E.J. Wilson (Eds). The SE Asian gateway: history and tectonics of the Australia-Asia collision. Geological Society of London, Special Publications. 355. 241266.

[33] Wilson, M.E.J. (Eds). 2011. The SE Asian gateway: history and tectonics of the Australia-Asia collision, Geological Society of London, Special Publication. 355. 241-166 
[34] Woodruff, D.S. 2010. Biogeography and conservation in Southeast Asia: how 2.7 million years of repeated environmental fluctuations affect today's patterns and the future of the remaining refugial-phase biodiversity. Biodiv. Conserv. 19. 919-941.

[35] Kershaw, A.P., S. van der Kaars, J.R. Flenley. 2007. The quaternary history of far eastern rainforests. In: Bush, M.B., J.R. Flenley (Eds). Tropical rainforest responses to climate change. Springer, Berlin. 77-115.

[36] Haywood, A.M., H.J. Dowsett, P.J. Valdes, D.J. Lunt, J.E. Francis, B.W. Sellwood. 2009. Introduction. Pliocene climate, processes and problems. Philos. Trans. R. Soc. A. 367. 3-17.

[37] Heaney, L.R. 1991. A synopsis of climatic and vegetational change in Southeast Asia. Clim. Change. 19. 53-61.

[38] Wallace, A.R. 1860. On the zoological geography of the Malay Archipelago. J. Linn. Soc. London. 4. 172-184.

[39] Dahruddin, H., A. Hutama, F. Busson, S. Sauri, R. Hanner, P. Keith, R. Hadiaty, N. Hubert. 2016. Revisiting the ichthyodiversity of Java and Bali through DNA barcodes: taxonomic coverage, identification accuracy, cryptic diversity and identification of exotic species. Mol. Ecol. Resour. 17(2). DOI: 10.1111/1755-0998.12528.

[40] Mayr, E. 1944. Wallace's Line in the light of recent zoogeographic studies. Am Mus. Nat. Hist. 19. 1-14.

[41] Komaki, S., S.M. Lin, M. Nozawa, S. Oumi, M. Sumida, T. Igawa. 2016. Fine-scale demographic processes resulting from multiple overseas colonization events of the Japanese stream tree frog, Buergeria japonica. J. Biogeogr. 1-12.

[42] van den Bergh, GD., J. de Vos, P.Y. Sondaar. 2001. The late quaternary palaeogeography of mammal evolution in the Indonesian Archipelago. Palaeogeogr. Palaeoclimatol. Palaeoecol. 171. 385-408.

[43] Heatwole, H., R. Levins. 1972. Biogeography of the Puerto Rican Bank: floatsam transport of terrestrial animals. Ecology. 53. 112-117.

[44] Prescott, J.H. 1959. Rafting of jack rabbit on kelp. J. Mammal. 40. 443.

[45] Censky, E.J., K. Hodge, J. Dudley. 1998. Over-water dispersal of lizards due to hurricanes. Nature. 395. 556.

[46] Thiel, M., L. Gutow. 2005. The ecology of rafting in the marine environment. I. The floating substrata Oceanogr. Mar. Biol. Annu. Rev. 42. 181-263.

[47] Godfrey, J.S. 1996. The effect of the Indonesian throughflow on ocean circulation and heat exchange with the atmosphere: a review. J. Geophys. Res. 101. 12217-12238.

[48] Metzger, E.J., H.E. Hurlburt. 1996. Coupled dynamics of the South China Sea, the Sulu Sea and the Pacific Ocean. J. Geophys. Res. 101. 12331-12352.

[49] Arévalo, E., W.S. Jack Jr., S.K. Davis. 1994. Mitochondrial DNA sequence divergence and phylogenetic relationships among eight chromosome races of the Sceloporus grammicus complex (Phrynosomatidae) in Central Mexico. Syst. Biol. 43. 387-418. 
(Priambodo et al)

Supplementary 1. List of the sample used in this study

\begin{tabular}{|c|c|c|c|c|c|c|}
\hline \multirow{2}{*}{ Species } & \multirow{2}{*}{ Code* } & \multirow{2}{*}{ Locality } & \multicolumn{4}{|c|}{ Accession number } \\
\hline & & & $16 S$ & ND4 & 7IßßFIB & 3ITBP \\
\hline C. insularis & 1 & E Java & MG561477 & MG561528 & MG561620 & MG561575 \\
\hline C. insularis & 2 & E Java & MG561478 & MG561529 & MG561621 & MG561576 \\
\hline C. insularis & 3 & E Java & MG561479 & MG561530 & MG561622 & MG561577 \\
\hline C. insularis & 10 & Malang, E Java & MG561486 & MG561537 & - & MG561584 \\
\hline C. insularis & 21 & $\begin{array}{l}\text { Bondowoso, } \\
\text { E Java }\end{array}$ & MG561497 & MG561548 & MG561632 & MG561594 \\
\hline C. insularis & 22 & $\begin{array}{l}\text { Bondowoso, } \\
\text { E Java }\end{array}$ & MG561498 & MG561549 & - & - \\
\hline C. insularis & 23 & $\begin{array}{l}\text { Bondowoso, } \\
\text { E Java }\end{array}$ & MG561499 & MG561550 & - & MG561595 \\
\hline C. insularis & 24 & $\begin{array}{l}\text { Bondowoso, } \\
\text { E Java }\end{array}$ & MG561500 & MG561551 & - & MG561596 \\
\hline C. insularis & 25 & $\begin{array}{l}\text { Bondowoso, } \\
\text { E Java }\end{array}$ & MG561501 & MG561552 & - & MG561597 \\
\hline C. insularis & 27 & $\begin{array}{l}\text { Bondowoso, } \\
\text { E Java }\end{array}$ & MG561503 & MG561554 & - & MG561599 \\
\hline C. insularis & 28 & Kediri, E Java & MG561504 & MG561555 & - & MG561600 \\
\hline C. insularis & 37 & Purnama beach, Bali & MG561513 & MG561564 & - & MG561608 \\
\hline C. insularis & 38 & Purnama beach, Bali & MG561514 & MG561565 & - & MG561609 \\
\hline C. insularis & 39 & Purnama beach, Bali & MG561515 & MG561566 & MG561638 & MG561610 \\
\hline C. insularis & 56 & Tanah Lot, Bali & MG561518 & MG561568 & MG561639 & MG561613 \\
\hline C. insularis & 58 & $\begin{array}{l}\text { Suranadi, } \\
\text { W Lombok }\end{array}$ & MG561520 & MG561570 & MG561641 & MG561615 \\
\hline C. insularis & 59 & $\begin{array}{l}\text { Suranadi, } \\
\text { W Lombok }\end{array}$ & MG561521 & MG561571 & MG561642 & MG561616 \\
\hline C. insularis & 60 & $\begin{array}{l}\text { Suranadi, } \\
\text { W Lombok }\end{array}$ & MG561522 & MG561572 & MG561643 & MG561617 \\
\hline C. insularis & 61 & $\begin{array}{l}\text { Suranadi, } \\
\text { W Lombok }\end{array}$ & MG561523 & MG561573 & MG561644 & MG561618 \\
\hline C. insularis & 62 & $\begin{array}{l}\text { Jonggat, } \\
\text { C Lombok }\end{array}$ & MG561524 & MG561574 & MG561645 & MG561619 \\
\hline C. insularis & A109/A96 & E Java/Indo & AY352738 & AY352833 & GQ428347 & - \\
\hline C. insularis & B7 & W Timor & AY059550 & AY059586 & DQ116978 & DQ117500 \\
\hline C. albolabris & 34 & $\begin{array}{l}\text { Wonosobo, } \\
\text { C Java }\end{array}$ & MG561510 & MG561561 & MG561636 & MG561606 \\
\hline
\end{tabular}

*The code start with a number were obtained in this study. Whereas the code start with alphabet was obtained from Genbank. (C: Central, E: East, W: West)

Supplementary 2. Primers and sources used in this study

\begin{tabular}{cccc}
\hline Genes & Primers & Primer sequences & References \\
\hline 16S & 16Sf4 & 5'-CTTGTACCTTTTGCATCATGGT-3' & This study \\
& 16Sr2 & 5'-CCGGTCTGAACTCAGATCACGT-3' & This study \\
ND4 & ND4 & 5'-CACCTATGACTACCAAAAGCTCATGTAGAAGC-3' & Arevalo et al [49] \\
& LEU & 5'-CATTACTTTTACTTGGATTTGCACCA-3' & Arevalo et al [49] \\
& ND4-R & 5'-TTACCAGATTGAAGAGTTAGCAGGTCTT-3' & This study \\
7IBFIB & TRIMFIB-BI7U & 5'-AGAGACAATGATGGATGGTAAG-3' & Creer et al [13] \\
& TRIMFIB-B17L & 5'-CCTTTTGGGATCTGGGTGTA-3' & Creer et al [13] \\
& 7IBFIB-2F & 5'-TATAGCACCTGCAAAACG-3' & This study (Nested PCR) \\
& 7IBFIB-2R & 5'-CTTGCCTTATCTTACTATGTG-3' & This study (Nested PCR) \\
3ITBP & TRIMTBPI3F & 5'-CCTTTACCAGGAACCACACC-3' & Creer et al [13] \\
& TRIMTBPI3R & 5'-GAAGGGCAATGGTTTTAG-3' & Creer et al [13] \\
& 3ITBP-2F & 5'-CAGGTTCTACTCTGCTCACA-3' & This study (Nested PCR) \\
& 3ITBP-2R & 5'-AATGGACTCCAGAAGATG-3' & This study (Nested PCR) \\
\hline
\end{tabular}

